\title{
Effect of Sodium Chloride on Response of Two Wheat Cultivars (Triticum aestivum L.) at Germination and Early Seedling Stages
}

\author{
Abdoun H. Alwan ${ }^{1}$, Khalid A. Hussein ${ }^{1}$, Khudhair A. Jaddoa ${ }^{2}$ \\ ${ }^{1}$ Department of Biology, College of Science- University of Kerbala -Kerbala City, Iraq \\ ${ }^{2}$ Department of Field Crop Sciences, College of Agriculture-University of Baghdad -Baghdad, Iraq \\ Email address: \\ abdounha@yahoo.com (A. H. Alwan),khdhayerjaddoa@yahoo.com (K. A. Jaddoa)
}

\section{To cite this article:}

Abdoun H. Alwan, Khalid A. Hussein, Khudhair A. Jaddoa. Effect of Sodium Chloride on Response of Two Wheat Cultivars (Triticum Aestivum L.) at Germination and Early Seedling Stages. International Journal of Applied Agricultural Sciences.

Vol. 1, No. 3, 2015, pp. 60-65. doi: 10.11648/j.ijaas.20150103.13

\begin{abstract}
An experiment was conducted in pots to study the effect of sodium chloride levels $(0,50,100$,and 150$) \mathrm{meg}^{-\mathrm{L}^{-1}}$ on two wheat cultivars AL-Hussein and AL-Rasheed in terms of germination percentages, seedling vigour index, lengths and dry weights of shoot and root, phytotoxicity of shoot and root, stress intensity, stress tolerance index, electrolyte leakage percent and chlorophyll stability index. Salinity treatments were applied from sowing till the end of the experiment. Factorial experiment with CRD design with three replicates was used. Results revealed that, AL-Hussein cultivar gave the highest response to salinity compared with AL-Rasheed in terms of germination percentage., seedling growth, shoot and root dry weights, seedling vigour index, stress tolerance index and chlorophyll stability index. Meanwhile, AL-Rasheed cultivar gave the highest values of shoot and root phytotoxicity stress intensity and electrolyte leakage percent. Sodium chloride significantly affected all studied characteristics, but the highest (level $150 \mathrm{meg} . \mathrm{L}^{-1}$ ) gave higher increase or decrease in studied characteristics compared with the control. These results indicated that, tolerance of AL-Hussein cultivar to salinity was correlated with stress tolerance index and chlorophyll stability index under salinity stress.
\end{abstract}

Keywords: Salinity, Nacl, Wheat, Growth, Salinity Tolerance

\section{Introduction}

The salinity is considered the main limiting problem of the plant production in irrigated area especially in arid and semi-arid zones. It causes negative effects on germination percent, growth and productivity of field crops [1]. Salinization effect in many irrigated areas is caused by using saline irrigation where more than 45 million of irrigated land are influenced by salinity. Yearly, one million and a half hectare are discarded form the production as a result of increasing salinity levels in the soil [2]. High salinity influences plant growth and production in many ways such as water stress, ion toxicity, nutritional disorders, oxidative stress, alteration of metabolic processes, plasma membrane disturbance and cell division and expansion [3]. Plants tolerate salinity via discard of salt from cells or tolerate its presence inside the cell [4].

Finding salt - tolerant genotypes through mechanism enable plant to tolerate salinity is considered one of the main treatment for this problem from one side and to alleviate the negative effects on the growth and production of different crops from another side. Wheat (the first crop in the world in cultivation area and production) is suffering from salinity problem although it is considered semi tolerant plant [5]. The tolerance for salinity is complex phenomenon controlled by many genes [4].

Water quality, climate conditions and crop variety may affect the tolerance of crops to salinity. The main features of salinity effect are the reduced of seed germination, seedling and root and shoot growth. Testing plants possess such a mechanism for $\mathrm{Na}$ discarding, ionic balance and high $\mathrm{K}$ absorption would be of importance. Therefore, this experiment was carried out to test two varieties of wheat namely: AL - Hussein which is recently selected (Jaddoa, 2015, Pers. comm. ) and AL- Rasheed (which is widely cultivated in Iraq). 


\section{Materials and Methods}

A pot experiment was conducted on Nov. 15th, 2015 in the Botanical Garden of College of Science, University of Kerbala. A completely Randomized Design (CRD) in a factorial manner with three replicates was adapted. The experiment included two factors i.e. two varieties of wheat namely AL -Hussein and AL -Rasheed, and four levels of $\mathrm{Na}$ $\mathrm{cl}(0,50,100$ and 150$)$ meq. $\mathrm{L}^{-1}$.Ten seeds from each variety were sown in $20 \mathrm{kgs}$. pot capacity, irrigated with the salinity treatments at full field capacity for 30 days early seedling stage, plants were carefully lifted from the pots, thoroughly washed to remove soil particles from the roots then divided into roots and shoots. The following characteristics were determined:

1. The germination percent: germination percent was calculated for emerged seeds 10 days alter sowing [6].

2. Seedlings were thinned to five seedlings after calculation of seed germination. After 15 days from sowing half dose of recommended nitrogen fertilizer was added. After 30 days form sowing, shoot height and root height were measured using a ruler. Roots and shoots were dried at $70 \mathrm{C}$. for one night and their weights were recorded.

3. The stress intensity (SI) according to the method of [7] on dry matter basis was calculated using the following equation :

$$
\text { Stress intensity }=1-(\mathrm{ysi} / \mathrm{ypi})
$$

Where:

Ysi: seedling dry weight of saline treatment.

Ypi: seedling dry weight of control treatment.

4. Measurement of stress tolerance index (STI) : stress tolerance index was calculated according to the equation of [8].

$$
\mathrm{STI}=(\text { Ypi } \times \text { Ysi }) / \mathrm{ypi}^{2} \text {. }
$$

Where STI: stress tolerance index.

Ypi: seedling dry weight of control treatment.

Ysi: seedling dry weight of saline treatment.

$\mathrm{Ypi}^{2}$ : square of seedling weight of control treatment.

5. Measurement of $\mathrm{Nacl}$ toxicity percent in root and shoot was calculated according to the following equation described by [9].

(\%) Phtotoxicity of shoot $=$ shoot length in treatment $/$ shoot length in control $(\%)$ Phytotoxicity of root $=$ root length in treatment / root length in control.

6. Seed vigour index calculated according to the following equation mentioned by [10]:

Seedling vigor index $=\%$ Germination $\times$ Seedling dry weight

7. Electrolyte leakage percent.

Electrolyte leakage percent was measured according to [11] as follow:
Five hundred $\mathrm{mg}$ of seedling leaves tissue were taken after washing by deionized water, cut into slices $2 \mathrm{~mm}$ in diameter placed in test tubes containing 10 deionized $\mathrm{H}_{2} \mathrm{O}$ then put on the shaker incubator at $5 \mathrm{C}^{\circ}$ for $24 \mathrm{hrs}$. The electrical conductivity (EC) was measured by using EC - meter, samples were then placed inside the autoclave at $120 \mathrm{C}^{\circ}$ for 20 minutes, the EC was measured (EC2) after cooling to room temperature. The electrolyte leakage percentage was finally calculated as follow :

$$
\% \text { Electrolyte leakage }=(\mathrm{EC} 1 / \mathrm{EC} 2) \times 100 .
$$

8. Chlorophyll stability index was calculated according to the equation described by [12].

Chlorophyll stability index $=($ chlorophyll content in stress treatment)/ (chlorophyll content in control treatment) x 100 .

9. Statistical analysis: Data were statistically analyzed, treatment were compared by using least significant difference at 0.05 probability level [13].

\section{Results}

\subsection{The Effect of Salinity Stress on the Germination Percent of Two Wheat Cultivars}

Data in table (1) revealed that, increasing salt concentration significantly decreased the percentage of germination. Seeds treated with $150 \mathrm{meg}$. L $\mathrm{L}^{-1} \mathrm{Nacl}$ gave $53.75 \%$ of seed germination. Whereas, the control treatment gave the highest value $(95.00 \%)$ alter 10 days from sowing.

Wheat cultivar varied significantly. AL- Hussein cultivar gave the highest percent of seed germination (84.13\%) compared with AL- Rasheed cultivar which gave 78.13\%. AL- Hussein cultivar was higher than AL- Rasheed in germination percentage by $7.6 \%$. The interaction between these two factors had a marked effect on the germination percent where the highest value was obtained from ALHussein cultivar at 50 meq. $\mathrm{L}^{-1} \mathrm{Nacl}$ giving $98 \%$ ) while at the highest salinity level the lowest value was associated with the AL- Rasheed cultivar grown at $150 \mathrm{meg}$. $\mathrm{L}^{-1} \mathrm{Nacl}$ giving $51.70 \%$ of germination.

Table (1). Effect of Nacl level on the germination percent of two wheat cultivars.

\begin{tabular}{llllll}
\hline $\begin{array}{l}\text { Nacl meg.L } \\
\text { cultivars }\end{array}$ & $\mathbf{0}$ & $\mathbf{5 0}$ & $\mathbf{1 0 0}$ & $\mathbf{1 5 0}$ & Mean \\
\hline AL-Hussein & 97.20 & 98.00 & 85.50 & 55.80 & 84.13 \\
AL-Rasheed & 92.80 & 94.30 & 73.90 & 51.70 & 78.18 \\
Mean & 95.00 & 96.15 & 79.70 & 53.75 & \\
L.S.D $(0.05)$ & $\mathrm{Na} \mathrm{cl}=1.37$ cultivar $=0.97$ Interaction $=1.94$ \\
\hline
\end{tabular}

\subsection{The Effect of Salinity Stress on the Plant Height (cm)} of Two Wheat Cultivars

The plant height was significantly influenced by $\mathrm{Na} \mathrm{cl}$ levels treatments (Table 2). The plant height decreased significantly with increasing the $\mathrm{Na} \mathrm{cl}$ level. The highest 
reduction was at $150 \mathrm{meg}$. $\mathrm{L}^{-1}$. Also the results showed that AL- Hussein cultivar was taller than AL- Rasheed by $28.9 \%$ when grown under salinity condition. On the other hand, while the interaction between these two factors, showed there is not significant effect on plant height.

Table (2). Effect of $\mathrm{Na}$ cl levels on the plant height of two wheat cultivars.

\begin{tabular}{llllll}
\hline $\begin{array}{l}\text { Na cl meg. } \mathbf{L}^{-} \\
\text {cultivars }\end{array}$ & $\mathbf{0}$ & $\mathbf{5 0}$ & $\mathbf{1 0 0}$ & $\mathbf{1 5 0}$ & Mean \\
\hline AL-Hussein & 30.87 & 32.10 & 24.60 & 14.40 & 25.49 \\
AL-Rasheed & 21.50 & 30.90 & 15.30 & 11.80 & 19.78 \\
Mean & 25.68 & 31.50 & 22.45 & 15.60 & \\
L.S.D $(0.05)$ & $\mathrm{N} \mathrm{a} \mathrm{Cl}=2.78$ cultivar $=1.54$ Interaction $=\mathrm{N} . \mathrm{S}$ \\
\hline
\end{tabular}

\subsection{Effect of Salinity Stress on the Roots Length (cm) of Two Wheat Cultivars}

Table (3) showed that, neither the cultivar nor the interaction had a significant effect on roots length. On the other hand, increasing $\mathrm{Na}$ cl levels significantly affected roots length where the roots length decreased by $40.2 \%$ as $\mathrm{Na}$ cl increased from 0 to 150 meg. $\mathrm{L}^{-1}$.

Table (3). Effect of NaCL levels on the roots length (cm) of two wheat cultivars.

\begin{tabular}{llllll}
\hline $\begin{array}{l}\text { Na cl meg. } \mathbf{L}^{-1} \\
\text { cultivars }\end{array}$ & $\mathbf{0}$ & $\mathbf{5 0}$ & $\mathbf{1 0 0}$ & $\mathbf{1 5 0}$ & Mean \\
\hline AL-Hussein & 8.47 & 9.80 & 6.10 & 6.50 & 7.72 \\
AL-Rasheed & 13.10 & 8.80 & 7.73 & 6.40 & 9.01 \\
Mean & 10.78 & 9.30 & 6.91 & 6.45 & \\
L.S.D(0.05) & Nacl =3.38 cultivar =N.S Interaction $=$ N.S & \\
\hline
\end{tabular}

\subsection{The Effect of Salinity Stress on the Shoot Dry Weight (g) of Two Wheat Cultivars.}

Table (4) showed that, the highest shoot dry weight was achieved by AL- Hussein cultivar giving $0.129 \mathrm{~g}$ whereas, AL- Rasheed cultivar gave 0.054 , shoot dry weight of ALHussein was $135.2 \%$ higher than AL- Rasheed cultivar The salinity also showed a significant effect on the shoot dry weight where it decreased from 0.073 to $0.036 \mathrm{~g}$ giving $50.7 \%$ reduction due to increasing $\mathrm{Na}$ cl from 0 to $150 \mathrm{meg}$. $\mathrm{L}^{-1}$.

Table (4). Effect of $\mathrm{Na}$ cl levels on shoot dry weight (g) of two wheat cultivars.

\begin{tabular}{llllll}
\hline $\begin{array}{l}\text { Na cl meg. } \mathbf{L}^{-1} \\
\text { cultivars }\end{array}$ & $\mathbf{0}$ & $\mathbf{5 0}$ & $\mathbf{1 0 0}$ & $\mathbf{1 5 0}$ & Mean \\
\hline AL-Hussein & 0.085 & 0.261 & 0.093 & 0.039 & 0.127 \\
AL-Rasheed & 0.061 & 0.080 & 0.043 & 0.033 & 0.054 \\
Mean & 0.073 & 0.170 & 0.068 & 0.036 & \\
L.S.D $(0.05)$ & $\mathrm{Na} \mathrm{cl}=0.091$ cultivar $=0.062$ Interaction $=\mathrm{N} . \mathrm{S}$ \\
\hline
\end{tabular}

\subsection{The Effect of Salinity Stress on Roots Dry Weight (g/plant) of Two Wheat Cultivar}

Increasing $\mathrm{Na}$ cl level up to $150 \mathrm{meg}$. $\mathrm{L}^{-1}$ decreased the root dry weight by $96.8 \%$. No significant differences between cultivars in their roots dry weight. (Table 5).The interaction between the cultivars and $\mathrm{Na} \mathrm{cl}$ also affected this trait significantly. The highest root dry weight was obtained by at AL- Hussein cultivar the control treatment giving 0.075 $\mathrm{g}$ while the lowest value resulted from both cultivars at 150 meg. $\mathrm{L}^{-1} \mathrm{Nacl}$ giving $0.002 \mathrm{~g}$. Also the results showed that there is not significant differences between cultivars in their roots dry weight.

Table (5). The effect of Nacl Levels on the roots dry weight (g) of two wheat cultivars.

\begin{tabular}{llllll}
\hline Na cl meg.L & -1 \\
AL-Hussein & 0.075 & 0.032 & 0.021 & 0.002 & 0.032 \\
AL-Rasheed & 0.050 & 0.062 & 0.007 & 0.002 & 0.030 \\
Mean & 0.063 & 0.047 & 0.014 & 0.002 & \\
L.S.D $(0.05)$ & $\mathrm{Na} \mathrm{Cl}=0.005$ cultivar $=$ N.S Interaction $=0.006$ \\
\hline
\end{tabular}

\subsection{The Effect of Viability Coefficient of Two Wheat Cultivars Seedlings}

Data in (table 6) revealed that, a marked reduction in viability coefficient was obtained due to increasing $\mathrm{Na} \mathrm{Cl}$ levels from 0 to $150 \mathrm{megL}^{-1}$ reaching $88 \%$. AL- Hussein cultivar gave a profound increase than AL- Rasheed cultivar giving $144.6 \%$ increase. AL- Hussein cultivar at 0 meg. $\mathrm{L}^{-1}$ $\mathrm{Na}$ cl gave the highest value (26.215) whereas AL- Rasheed cultivar at $150 \mathrm{meg} . \mathrm{L}^{-1} \mathrm{Na} \mathrm{cl}$ gave the lowest (1.826).The viability coefficient of both cultivars decreased with increasing salinity level (table 6), but the lowest reduction were at150 meg $\mathrm{L}^{-1}$.

Table (6). The effect of $\mathrm{Na}$ Cl levels on the viability coefficient of two wheat cultivars.

\begin{tabular}{llllll}
\hline $\begin{array}{l}\text { Na cl meg. } \mathbf{L}^{-} \\
\text {cultivars }\end{array}$ & $\mathbf{0}$ & $\mathbf{5 0}$ & $\mathbf{1 0 0}$ & $\mathbf{1 5 0}$ & Mean \\
\hline AL-Hussein & 26.215 & 19.141 & 6.726 & 2.345 & 13.607 \\
AL-Rasheed & 8.508 & 8.765 & 3.152 & 1.826 & 5.563 \\
Mean & 17.361 & 13.953 & 4.939 & 2.086 & \\
L.S.D $(0.05)$ & $\mathrm{Na} \mathrm{cl}=0.653$ cultivar $=0.462$ Interaction $=0.924$ \\
\hline
\end{tabular}

\subsection{The Effect of Salinity Stress on, the Shoot Phytotoxicity Percent of Two Cultivars}

Table (7). The effect of salinity stress on the roots phytotoxicity percent of two wheat cultivars.

\begin{tabular}{llllll}
\hline $\begin{array}{l}\text { Na cl meg. } \mathbf{L}^{-1} \\
\text { cultivars }\end{array}$ & $\mathbf{0}$ & $\mathbf{5 0}$ & $\mathbf{1 0 0}$ & $\mathbf{1 5 0}$ & Mean \\
\hline AL-Hussein & 0.136 & 0.138 & 0.227 & 0.489 & 0.248 \\
AL-Rasheed & 0.151 & 0.166 & 0.233 & 0.366 & 0.229 \\
Mean & 0.144 & 0.152 & 0.230 & 0.428 & \\
L.S.D $(0.05)$ & $\mathrm{Na} \mathrm{cl}=0.002$ cultivar $=0.001$ & Interaction $=0.002$ \\
\hline
\end{tabular}

Table (7) showed that phytotoxicity significantly increased from 0.144 to $0.152,0.230$ and $0.428 \%$ due to increasing salinity from 0 to 50,100 and $150 \mathrm{meg}$. $\mathrm{L}^{-1}$ giving an increment of $197.2 \%$. AL- Hussein cultivar gave higher value of phytotoxicity coefficient than AL- Rasheed cultivar. There was a significant effect of the interaction on this trait. AL- 
Hussein cultivar grown with 150 meg. $\mathrm{L}^{-1}$ gave the highest value $0.489 \%$ whereas the lowest value was gained from the same cultivar grown without salinity $(0.136 \%)$.

\subsection{The Effect of Salinity Stress on the Roots Phytotoxicity Percent of Two Wheat Cultivars}

Data in Table (8) revealed that $\mathrm{Na}$ cl level significantly affected the toxicity percentage of root where the highest value was associated with $150 \mathrm{meg}$. $\mathrm{L}^{-1}$ treatment( 0.945). Cultivars differed significantly in this trait. AL- Hussein cultivar was less affected than AL- Rasheed where the difference was $12.2 \%$. There was a significant effect due to the interaction between $\mathrm{Na} \mathrm{cl}$ and cultivar, where the highest value accompanied AL- Rasheed cultivar grown with 150 meg. $\mathrm{L}^{-1}$ whereas the lowest value was obtained from ALHussein cultivar grown either without $\mathrm{Na} \mathrm{cl}$ or with 50 meg. $\mathrm{L}^{-1} \mathrm{Na}$ cl giving $0.196 \%$.

Table (8). The effect of $\mathrm{Na}$ cl levels on the roots phytotoxicity percent of two wheat cultivars.

\begin{tabular}{llllll}
\hline $\begin{array}{l}\text { Na cl meg.L-1 } \\
\text { cultivars }\end{array}$ & $\mathbf{0}$ & $\mathbf{5 0}$ & $\mathbf{1 0 0}$ & $\mathbf{1 5 0}$ & Mean \\
\hline AL-Hussein & 0.196 & 0.196 & 0.427 & 0.479 & 0.324 \\
AL-Rasheed & 0.201 & 0.328 & 0.405 & 0.511 & 0.361 \\
Mean & 0.198 & 0.262 & 0.416 & 0.495 & \\
L.S.D $(0.05)$ & \multicolumn{6}{l}{$\mathrm{Na} \mathrm{cl}=0.050$ cultivar $=0.036$ Interaction $=0.071$} \\
\hline
\end{tabular}

\subsection{The Effect of Salinity Stress on the Stress Tolerance Index (STI) of Two Wheat Cultivars}

Table (9) showed that cultivars were differed significantly in the (STI), the (STI) was higher in AL- Hussein cultivar giving an increment of percent reached 50.6\%. Stress tolerance index decreased with increasing $\mathrm{Na}$ cl levels where it decreased from 1.05 at the control to 0.267 at $150 \mathrm{meg} . \mathrm{L}^{-1}$ $\mathrm{Na}$ cl. The interaction effect on (STI) was significant. ALHussein cultivar grown with 50 meg. $\mathrm{L}^{-1}$ gave the highest value (1.437) whereas AL- Rasheed cultivar gave the lowest value (0.256), when grown in $150 \mathrm{meg} . \mathrm{L}^{-1}$.

Table (9). The effect of $\mathrm{Na}$ cl levels on the stress tolerance index (STI)of two wheat cultivars.

\begin{tabular}{llllll}
\hline $\begin{array}{l}\text { Na cl meg.L-1 } \\
\text { cultivars }\end{array}$ & $\mathbf{0}$ & $\mathbf{5 0}$ & $\mathbf{1 0 0}$ & $\mathbf{1 5 0}$ & Mean \\
\hline AL-Hussein & 1.323 & 1.437 & 0.512 & 0.278 & 0.887 \\
AL-Rasheed & 0.778 & 0.779 & 0.542 & 0.256 & 0.589 \\
Mean & 1.050 & 1.108 & 0.527 & 0.267 & \\
L.S.D $(0.05)$ & \multicolumn{7}{l}{$\mathrm{Na} \mathrm{cl}=0.100$ Cultivar $=0.071$ Interaction $=0.142$} \\
\hline
\end{tabular}

\subsection{The Effect of Salinity Stress on the Stress Intensity} (IS) of Two Wheat Cultivars

Higher stress intensity was recorded with AL-Rasheed cultivar (0.430) (Table 10). Increasing salinity caused a marked increase in This trait, where control treatment gave 0.196 whereas, plant grown with $150 \mathrm{meg}$. $\mathrm{L}^{-1}$ gave 0.731 . The interaction between the studied factors also affected the stress intensity significantly where AL- Hussein cultivar grown with $50 \mathrm{meg}$. $\mathrm{L}^{-1}$ gave the lowest value $(0.189)$ while the same cultivar grown with $150 \mathrm{meq} . \mathrm{L}^{-1}$ gave the highest value $(0.740)$.

Table (10). The effect of $\mathrm{Na}$ cl levels on the stress intensity (IS) of two wheat cultivars.

\begin{tabular}{llllll}
\hline $\begin{array}{l}\text { Na cl meg.L-1 } \\
\text { cultivars }\end{array}$ & $\mathbf{0}$ & $\mathbf{5 0}$ & $\mathbf{1 0 0}$ & $\mathbf{1 5 0}$ & Mean \\
\hline AL-Hussein & 0.191 & 0.189 & 0.579 & 0.740 & 0.425 \\
AL-Rasheed & 0.200 & 0.197 & 0.603 & 0.721 & 0.430 \\
Mean & 0.196 & 0.193 & 0.591 & 0.731 & \\
L.S.D $(0.05)$ & $\mathrm{Na} \mathrm{cl}=0.043$ cultivar $=0.030$ Interaction $=0.060$ \\
\hline
\end{tabular}

\subsection{The Effect of Salinity Stress on the Chlorophyll} Stability Index of Two Wheat Cultivars

Table (11) revealed that, $\mathrm{Na} \mathrm{cl}$ treatment and the interaction significantly affected the chlorophyll stability index. Higher value was obtained from control treatment (1.095) and lower value was obtained from 150 meg. L-1 Na cl treatment, recording $63.3 \%$ reduction. AL- Hussein cultivar was superior where increased by $15.3 \%$ over ALRasheed cultivar. However.AL- Hussein cultivar grown with 150 meg. L-1 Na cl gave lower value 0.357 whereas the same cultivar grown with $50 \mathrm{meg}$. L-1 Na cl gave the highest value (1.220).

Table (11). The effect of $\mathrm{Na}$ cl levels on the chlorophyll stability index of two wheat cultivars.

\begin{tabular}{llllll}
\hline $\begin{array}{l}\text { Na cl meg. } \mathbf{L}^{-1} \\
\text { cultivars }\end{array}$ & $\mathbf{0}$ & $\mathbf{5 0}$ & $\mathbf{1 0 0}$ & $\mathbf{1 5 0}$ & Mean \\
\hline AL-Hussein & 1.201 & 1.220 & 0.572 & 0.357 & 0.838 \\
AL-Rasheed & 0.990 & 0.899 & 0.572 & 0.447 & 0.727 \\
Mean & 1.095 & 1.060 & 0.572 & 0.402 & \\
L.S.D $(0.05)$ & \multicolumn{6}{l}{ Na cl $=0.46$ 1cultivar $=0.326$} & Interaction $=0.651$ \\
\hline
\end{tabular}

\subsection{The Effect of Salinity Stress on Plasma Membrane Injury of Two Wheat Cultivars}

The effect of $\mathrm{Na} \mathrm{cl}$ on the permeability of plasma membrane is shown in (Table 12) AL- Hussein cultivar was less affected than AL- Rasheed cultivar where the reduction was $14.8 \%$. Increasing $\mathrm{Na} \mathrm{cl}$ from 0 to $150 \mathrm{meg}$. $\mathrm{L}^{-1}$, the plasma membrane injury increased from 25.559 to $42.187 \%$ i.e. increased by $65.1 \%$. The interaction between their two factors significantly affected the membrane injury value where AL- Hussein cultivar grown with $50 \mathrm{meg} . \mathrm{L}^{-1}$ gave the lowest value (20.110) whereas AL- Rasheed cultivar, grown with150 meg. $\mathrm{L}^{-1} \mathrm{NaCl}$ gave the highest value.

Table (12). The effect of $\mathrm{Na}$ cl levels on the membrane injury of two wheat cultivars.

\begin{tabular}{llllll}
\hline $\begin{array}{l}\text { Na cl meg. } \mathbf{L}^{\mathbf{1}} \\
\text { cultivars }\end{array}$ & $\mathbf{0}$ & $\mathbf{5 0}$ & $\mathbf{1 0 0}$ & $\mathbf{1 5 0}$ & Mean \\
\hline AL-Hussein & 21.821 & 20.110 & 36.764 & 40.840 & 29.884 \\
AL-Rasheed & 29.297 & 31.447 & 36.017 & 43.535 & 35.074 \\
Mean & 25.559 & 25.779 & 36.391 & 42.187 & \\
L.S.D $(0.05)$ & $\mathrm{Na} \mathrm{cl}=2.870$ cultivar $=2.092$ Interaction $=4.059$ \\
\hline
\end{tabular}




\section{Discussion}

The difference between studied wheat cultivars in the germination percent could be attributed to their genetic differences [14]. The reduction in germination percentage due to the salinity treatment may be attributed to the direct effect of osmosis and to the salts toxicity where salts accumulate inside the seed by the imbibition of water leading to negative effect on $\mathrm{GA}_{3}$ and the activity of $\alpha$ - amylase enzyme [15]. In addition, salinity could inhibit the consequence metabolism of seed germination [16].

The dry weights of vegetative and root parts were also reduced by $\mathrm{Na}$ cl treatment (Tables 7 and 8 ) in both cultivars of wheat. The cultivars differed in their response to salinity and their difference was attributed to the genetic variation [17]. The superiority of AL- Hussein cultivar in terms of salinity tolerance could be due to its mechanism in discarding and / or avoiding $\mathrm{Na}$ from active sites and keeping high concentration of $\mathrm{K}$ in different plant parts especially the upper leaves to maintenance of metabolic processes and synthesis of dry matter during different stages of growth. Increasing $\mathrm{Na} \mathrm{cl}$, however reduced the dry matter and this could be due to the reduction in the stability of chlorophyll (Table 11) and to the reduction in the dry matter accumulation [18]. The direct and in direct effects of salinity caused reduction in all metabolic processes which reduce the plant grow in all plant parts.

The reduction in plants height with increasing salinity in irrigation water is a result of direct negative effect on the enzymes activity in plant cells leading to the precipitation of proteins or to the inhibition of their active sites, this result was agreed with that found by [19] who stated that using saline water 4 to $10.5 \mathrm{ds}$. cm reduced leaves protein and consequently reduced the plant growth as a result of reducing the division, expansion and differentiation of leaves cells [20]. Moreover, increasing stress intensity and increasing stress tolerance in AL- Rasheed cultivar were important factors for plant to tolerate the salt effect and grow well under salinity conditions. This finding confirmed that, ALHussein cultivar possess tolerance mechanisms better than AL- Rasheed cultivar where the tolerance is highly correlated with discarding $\mathrm{Na}^{+}$and $\mathrm{cl}^{-}$ions from the vegetative part. These results are in accordance with those found by [21] with Leptochloafusca plant.The stability of chlorophyll is considered as an indicator or a parameter for plant tolerance. Therefore, the abundance of chlorophyll in the plants leaves is leading to increase the photosynthesis rate and consequently a high dry matter is produced. All these give evidence for the salt tolerance by the plant [22].

The toxic effect of $\mathrm{Na} \mathrm{cl}$ on the permeability of the plasma membrane is shown in Table (12). There was an adverse effect of $\mathrm{Na}$ on the membrane permeability compared with the control. These results are in accordance with that found by [23]. Under stress conditions, cell membrane will expose to some changes mostly leading to increase the permeability of membrane [24]. The activity of cell membrane in controlling the ions movement into and out of the cell is used as a test of injury in the cell membrane. Nevertheless, the plasma membrane permeability in term of EC confirmed that, AL- Rasheed cultivar was sensitive to $\mathrm{Na}$ cl. According to [25] and [26], plant species respond differently to the oxidative injury and these could be due to the difference in ant- oxidative systems under salinity stress. The tolerance to $\mathrm{Na}$ cl toxicity depends on the differences in the uptake of $\mathrm{Na}^{+}$ and $\mathrm{cl}^{-}$and their translocation and discarding.

\section{References}

[1] Jouyban, Z. (2012).The effects of salt stress on plant growth.Tech. J. Engin. \&App.Sci., 2 (1): 7-10.

[2] Munns, R. and Tester, M. (2008).Mechanisms of salinity tolerance. Annual Review of Plant Biology, 59: 651-681.

[3] Zhu, J.K. (2007).Plant Salt Stress.University of California, Riverside, California, USA.Advanced article.

[4] Petronia C. (2011).Abiotic Stress in Plants - Mechanisms and Adaptations (A Shanker, Ed.).InTech.

[5] Ragab, A.A.M., Hellal, F.A. and Abd El-Hady, M. (2008). Water salinity impacts on some soil properties and nutrients uptake by wheat plants in sandy and calcareous soil. Aust. J. Basic Appl. Sci., 2: 225-233.

[6] International Seed Testing Association (ISTA) (1999). International rules for seed testing. Seed Science and Technology, 27 Supplement, 333 pp.

[7] Fischer, R.A. and Murrer, R. (1978).Drought resistance in spring wheat cultivars. I. Grain yield response. Aust. J. Agric. Res., 29: 897-912.

[8] Fernandez, C. G. J. (1993). Effective selection criteria for assessing plant stress tolerance. In: Kuo, C. G. Adaptation of Food Crops to Temperature and Water Stress, pp. 257-270. AVRDC, Shanhua, Taiwan.

[9] Chou, C.H. and Lin, H.J. (1976). Autointoxication mechanism of Oriza sativa L. phytotoxic effects of decomposing rice residues in soil. J. Chem. Ecol., 2: 353-367.

[10] Hosseein, A.F.andKasra, M. (2011). Effect of hydropriming on seedling vigour in basil (Ocimumbasilicum L.) under salinity conditions. Adv.Envi. Biol., 5(5): 828-833.

[11] Lutts, S., Almansouri, M.andKinet, J.M. (2004). Salinity and water stress have contrasting effects on the relationship between growth and cell viability during and after stress exposure in durum wheat callus. Plant Sci., 167: 9-18.

[12] Murthy, K.S. and Majumder (1962). Modifications of the technique for the determination of chlorophyll stability index in relation to drought resistance in rice. Curr. Sci., 31: 470471.

[13] Steel, R.G.D., Torrie, J.H. and Dickie, D.A. (1997).Principles and Procedures of Statistics-A biometric Approach. 3rd edition. McGraw-Hill Publishing Company. Toronto.

[14] Sohn, Y.G.,.Lee, B.H., Kang, K.Y. and Lee, J.J. (2005). Effect of Nacl stress on germination, antioxidant responses, and proline content in two rice cultivars. J. P1. Boil., 48(2): 201208. 
[15] Begum, F., Karmoker, J. L., Fattah, Q. A. and Maniruzzaman,A.F.(1992).The effect of salinity on germination and its correlation with $\mathrm{Na}, \mathrm{K}$, and $\mathrm{Cl}$ accumulation on germinating seeds of Triticum aestivum cv. Akbar. Plant and Cell Physiology, 33(7): 1009-1014.

[16] Younis, A. F. and Hatata, M. A. (1977). Studies on the effects of certain salts on germination, growth of root, and metabolism. Plant and Soil, 34:183-200.

[17] Delzoppo, M., Galleschi, L., Onnis, A. and Saviozzi, F. (1999).Effect of salinity on water relations, sodium accumulation, chlorophyll content and protelytic enzymes in a wild Wheat.Bio.Plantarum. 42(1): 97-104.

[18] Parto, R. and Timothy, F. (2009).The ionic effect of $\mathrm{NaCl}$ on physiology and gene expression in rice genotypes differing in salt tolerance.Plant and Soil. 315 (1-2): 136-147.

[19] Soliman, M. S., Shalabi, H. G. and Campbell, W.F.(1994). Interaction of salinity, nitrogen and phosphorus fertilization on wheat. J. P1. Nutr., 17 (7) : $1163-1173$.

[20] Allen, R.G., Pereira, L.S. Raes, D. and Smith, M. (1998). Crop evapo - transperation : guide line for computing crop water requirement FAO. No. 56.
[21] Tawfik, M.M., Amany, A. Bahr and Salem, A.K.M. (2006). Response of kallar grass (leptochloafusca L.) to biofertilizer inoculation under different levels of seawater irrigation. J. Appl. Sci. Res., 2(12): 1203-1211.

[22] Mohan, M.M., Lakshmi, S.N., Ibrahim, S.M. (2000). Chlorophyll stability index. (CSI): its impact on salt tolerance in rice. IRRI newsletter, 38-39 pp.

[23] Inal, A. and Tarakcioglu, C. (2001). Effects of nitrogen forms on the growth, nitrate accumulation, membrane permeability, and nitrogen use efficiency of hydroponically grown bunch onion (Allium cepaL ) under boron deficiency and toxicity. J. Pl. Nutr., 24: 1521-1534.

[24] Blokhina, O., Violainen, E., Fagerstedt, K.V. (2003). Antioxidants, oxidative damage and oxygen deprivation stress. a review Ann. Bot.,91:179-194.

[25] Sairam, R.K. and Srivastava, G.C. (2002).Changes in antioxidant activity in sub-cellular fractions of tolerant and susceptible wheat genotypes in response to long term salt stress. Plant Sci., 162:897-904.

[26] Sairam, R.K. and Saxena, D.C. (2000). Oxidative stress and antioxidants inwheat genotypes: possible mechanism of water stress tolerance. J. Agro.Crop Sci.,184:55-61. 